\title{
Hunting from the air: A new record of predation of Agelaia testacea (Fabricius, 1804) (Vespidae: Polistinae) on a katydid Parascudderia sp. (Orthoptera: Tettigoniidae: Phaneropterinae) in the Peruvian Amazon
}

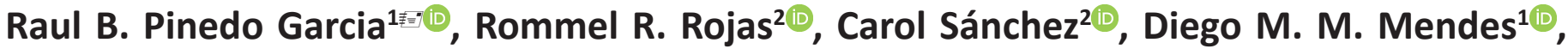 \\ Alexandre Somavilla ${ }^{1}$
}

${ }^{1}$ Instituto Nacional de Pesquisas da Amazônia - INPA, Manaus, Amazonas, Brazil. ${ }^{2}$ Universidad Nacional de la Amazonía Peruana UNAP, Iquitos, Loreto, Peru.

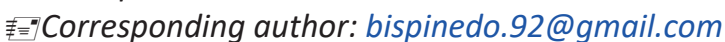

Edited by: Pedro G. B. Souza-Dias

Received: September 23, 2021. Accepted: February 09, 2022. Published: March 02, 2022.

\begin{abstract}
Social wasps capture adult and/or immature insects to feed their larvae. Frequent observations indicate mainly small or immature insects as their prey. However, there are very few records of social wasps as predators of larger living insects. Herein, we report a predation event carried out by an understory social wasp Agelaia testacea (Fabricius, 1804) (Vespidae: Polistinae) on an adult katydid Parascudderia sp. (Orthoptera: Tettigoniidae: Phaneropterinae), visibly larger than the wasp. This fact is added to a previous internet record of the same type of predation (Agelaia testacea in Tettigoniidae) for French Guiana in the Parc amazonien de Guyane. Studies like this contribute to understanding the trophic networks and hunting behavior of social wasps.
\end{abstract}

Keywords: Agelaia, behavior, insect predator, bush cricket.

Social wasps (Vespidae: Polistinae) are generalist feeders that primarily feed on nectar and fruits for carbohydrates. They also hunt arthropods as well as scavenge vertebrate and invertebrate carrion for proteins. Partly for the adult wasps themselves, but especially to feed their larval sisters awaiting in the nest (Richter 2000). Some predatory wasps play an important role in the natural control of insect pests (Picanço et al. 2012). They search and consume preys, adapt to environments, and compete for food, which make them highly efficient as predators (Santana et al. 2012). According to Prezoto et al. (2019), social wasps capture adult and/or immature insects to feed their larvae. Several accounts bring a detailed survey of prey captured by Polistines, like Polistes canadensis (Linnaeus, 1758), Polistes lanio (Fabricius, 1775), Polistes simillimus Zikán, 1951 and Polistes versicolor Olivier, 1971. Suggesting that these species have great value in the control of agricultural pests due to the amount of caterpillars used in their diet. Although, there are no reports for the occurrence of adult insects (Carpenter \& Marques 2001; Montefusco et al. 2017).

Epiponines, like Apoica pallens (Fabricius, 1804), Brachygastra lecheguana (Latreille, 1824), Polybia dimidiata (Olivier, 1791), Polybia ignobilis (Haliday, 1836), Polybia liliacea (Fabricius, 1804), Polybia occidentalis (Olivier, 1791), Polybia paulista (Ihering, 1896), Polybia sericea (Olivier, 1792), Protopolybia minutissima (Spinosa, 1851), Synoeca surinama (Linnaeus, 1767), and Synoeca virginea (Fabricius, 1804) also have a long record of capturing caterpillars (Hunt et al. 1995; Carpenter \& Marques 2001; Lourido et al. 2019). However, there are few records of social wasps predating adult living insects: Hunt et al. (1995) mention that forage loads of $A$. pallens may include chewed adult individuals like flies, small orthopterans, and a conglomerate of adult insects fragments, including small beetles elytra. Furthermore, the wasp apparently extracts the fluids from this chewed mass. Richards (1978) also recorded reproductive individuals of termites and ants being captured, mutilated, and stored in the nests of some species of Polybia Lepeletier, 1836.

Agelaia Lepeletier, 1836, is a swarming genera of Polistinae, grouped in Epiponini, a tribe with an exclusive Neotropical distribution -from Mexico to northern Argentina, being a conspicuous part of the social wasp fauna in tropical America (Richards 1978; Jeanne 1991; Cooper 2000; 2001). The genus has 31 valid species described, which are quite diverse in size, morphology, and nest architecture. The nests of Agelaia are commonly built in subterranean or arboreal cavities, which builds an aerial nest (Jeanne 1973) and is populated by a relatively large number of individuals, reaching colony sizes of millions of adults (Zucchi et al. 1995).

Agelaia testacea (Fabricius, 1804) (Vespidae: Polistinae) is a relatively large $(25 \mathrm{~mm})$ epiponine wasp, yellowish in color, with the posterior terga black. It is widely distributed in Northern South America, occurring in Colombia, Venezuela, Guyana, Suriname, French Guiana, Ecuador, Peru, Bolivia, and the Brazilian Amazon (IUNH, 2020). It is considered one of the most frequent social wasp species in the Amazon (Somavilla et al. 2014).

O'Donnell (1995) recorded several events of necrophagy by swarmfounding wasps of the genera Agelaia and Angiopolybia Araujo,1946 from Central and South America. There is a record among them from the wet lowland forest in Loreto Province (Peru), of three Epiponine foragers species: A. testacea, Agelaia hamiltoni (Richards, 1978), and Angiopolybia pallens (Lepeletier, 1836). Simultaneously collecting flesh from a large katydid (Orthoptera: Tettingoniidae) carcass in a seasonally flooded area. Nevertheless, predation on adult living insects larger than the wasps has been rarely recorded.

Recently, Frankhuizen et al. (2020) reported Agelaia pallipes (Olivier, 1972) attacking a nestling of the Lined Seedeater Sporophila lineola (Linnaeus, 1758), a small Neotropical songbird that lives in open habitats and builds cup-shaped nests (Ferreira \& Lopes 2017). In this case, the wasps cut small pieces of the bird's skin while still alive. Thus, compared with this situation, predation on larger-sized arthropods should not be common behavior in these wasps.

Here, we report a predation event, carried out by an understory scout individual of $A$. testacea on an individual of the katydid Parascudderia sp. (Orthoptera: Tettigoniidae: Phaneropterinae). The observation was made in a white sand "canpinarana" forest, 
on January 20th, 2021, during the onset of the summer season (temperature: $25^{\circ} \mathrm{C}$ ), at $16: 00 \mathrm{~h}$, during surveys in the study area of Puerto Almendra $\left(3^{\circ} 49^{\prime} 27^{\prime \prime} \mathrm{S}, 73^{\circ} 22^{\prime} 59^{\prime \prime} \mathrm{W}\right)$, Department of Loreto, Province of Maynas, District of San Juan, Nina-Rumi community, Peru. The predation event was recorded from approximately $1 \mathrm{~m}$ away, on a large leaf of a shrub. The individuals were not collected. Both, the katydid prey and wasp predator were observed for a few minutes and photographed. The wasp, of approximately $2.5 \mathrm{~cm}$, was holding the katydid, of approximately $5 \mathrm{~cm}$. The paralyzed katydid was apparently hunted recently, as no part of its body showed any damage. The wasp was holding and biting the katydid's cervix (a soft tissue) (Figure 1A, B). It was making strong backward movements, apparently trying to detach the katydid's head.

In a quick search on the internet for predation by social wasps in Tettigoniidae, we found another similar record of predation, in

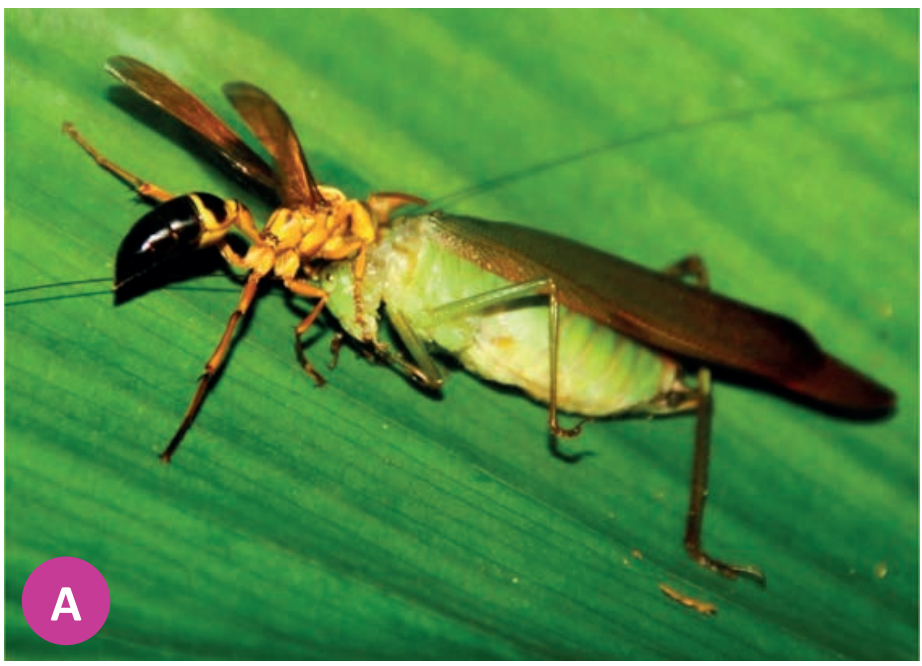

Figure 1A-B. Predation event carried out by an understory social wasp Agelaia testacea (Fabricius, 1804) (Vespidae: Polistinae) on a katydid Parascudderia sp. (Orthoptera: Tettigoniidae: Phaneropterinae) in Peru.

\section{Authors' Contributions}

RBP Garcia, R Rojas, A Somavilla - conceptualization; R Rojas, C Sánchez - record of predation in Peru; DMM Mendes, A Somavilla wasps and bush cricket identification; RBP Garcia, R Rojas, C Sánchez, DMM Mendes, A Somavilla - Writing and revising.

\section{Acknowledgments}

We sincerely thank Dr. Claire Villemant for her personal information of predation behavior by Agelaia testacea in Tettigonidae (Orthoptera) in Frech Guiana.

\section{Conflict of Interest Statement}

All authors declare that there is no conflict of interest for the publication of this manuscript.

\section{References}

Carpenter, J. M.; Marques, O. M. (2001) Contribuição ao Estudo Dos Vespídeos do Brasil (Insecta, Hymenoptera, Vespoidea, Vespidae). Universidade Federal da Bahia, Departamento de Fitotecnia, Bahia.

Cooper, M. (2000) Five new species of Agelaia Lepeletier (Hym., Vespidae, Polistinae) with a key to members of the genus. New synonymy and notes. Entomologist Monthly Magazine, 136: 177198.

Cooper, M. (2001) Two new species of Agelaia Lepeletier (Hym, Vespidae, Polistinae). Entomologist Monthly Magazine, 137: 233236.

Ferreira, D. D. F.; Lopes, L. E. (2017) Natural history of the Lined Seedeater Sporophila lineola (Aves: Thraupidae) in southeastern Brazil. Journal of Natural History, 51: 1425-1435. doi: 10.1080/00222933.2017.1319518

Frankhuizen, S.; Lopes, L. E.; Cunha, F. C. R. (2020) Social paper wasp
French Guiana, Parc amazonien de Guyane (2¹4'1.89" N 54²7'0.39 "W), through the link of the Muséum National d'Histoire Naturelle Inventaire National du Patrimoine Naturel. In this image, a specimen of Agelaia testacea is preying an undetermined adult individual of Tettigoniidae (MNHN 2021). According to researcher Dr. Claire Villemant: "this picture was taken in the morning after the end of light trapping when living insects attracted by the light were gathered around the trap, on the March 06th, 2015".

The predation behavior by Agelaia testacea in Tettigoniidae (Orthoptera) appears to be more common than previously documented, and it should probably be frequent in Amazonian environments. Studies like this contribute to the understanding of the trophic networks and hunting behavior of social wasps.

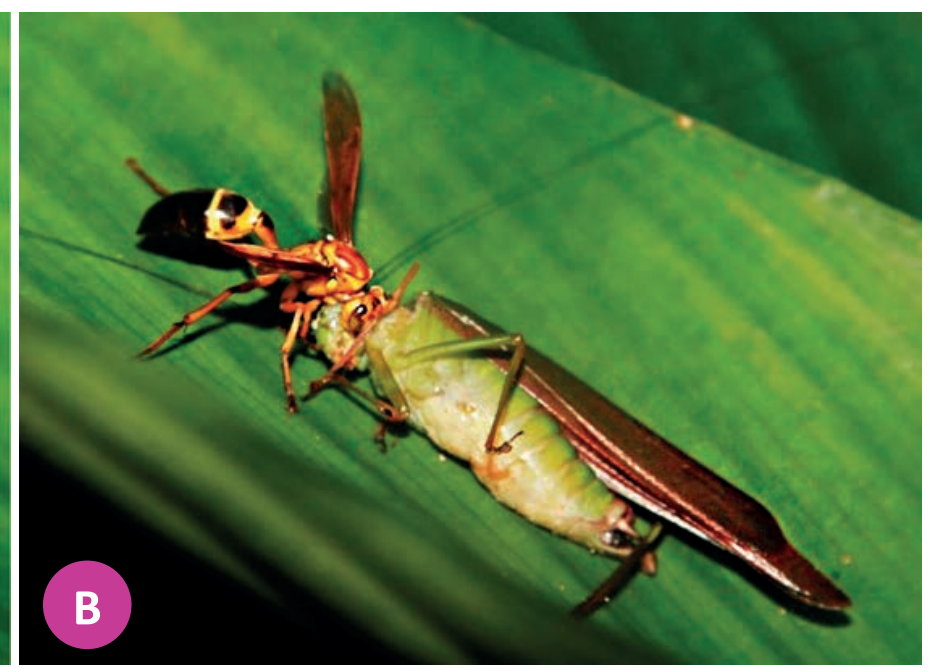

(Agelaia pallipes) predates songbird nestling. Ethology, 126: 10041006.

Jeanne, R. L. (1973) Aspects of the biology of Agelaia areata (Say) (Hymenoptera: Vespidae). Biotropica, 5(3): 183-198. doi: 10.1111/ eth.13076

Jeanne, R. L. (1991) The swarm-founding Polistinae. In: Ross, K. G.; Matthews, R. W. (Eds.), The Social Biology of Wasps, pp. 191-231. Cornell Univ. Press, Ithaca.

Hunt, J. H.; Jeanne, R. H.; Keeping, M. G. (1995) Observations on Apoica pallens, a nocturnal Neotropical social wasp (Hymenoptera: Vespidae, Polistinae, Epiponini). Insectes Sociaux, 42: 223-236. doi: 10.1007/bf01240417

IUNH - Natural History Laboratory Ibaraki University (2020) Checklist and/or Catalog of Social Wasps. http://iunh2.sci.ibaraki.ac.jp/ wasp/list. Access on: 05.v.2020.

Lourido, G. M.; Mahlmann, T.; Somavilla, A.; Guerra, K. F. G. (2019) Social Wasps as Biological Control Agents Against Diaphania hyalinata (Linnaeus, 1767) (Lepidoptera, Crambidae), a Cucumber Pest in Amazonas, Brazil. Sociobiology, 66: 610-613. doi: 10.13102/ sociobiology.v66i4.3576

MNHN - Muséum National d'Histoire Naturelle (Ed) (2021) Inventaire National du Patrimoine Naturel. https://inpn.mnhn.fr/espece/cd nom/759043. Access on: 05.v.2021.

Montefusco, M.; Gomes, F.B.; Somavilla, A.; Krug, C. (2017) Polistes Amazon: a Potential Biological Control Agent. Sociobiology, 64: 477-483. doi: 10.13102/sociobiology.v64i4.1936

O'Donnell, S. (1995) Necrophagy by Neotropical Swarm-Founding Wasps (Hymenoptera: Vespidae, Epiponini). Source: Biotropica, 27:133-136.

Picanço, M. C., Oliveira, I. R., Fernandes, F. L., Martinez, H. E. P., Bacci, L.; Silva, E. M. (2012) Ecology of Vespidae (Hymenoptera) predators in Coffea arabica plantations. Sociobiology, 59: 1269-1280. doi: canadensis (Linnaeus, 1758) (Vespidae: Polistinae) in the Western 
10.13102/sociobiology.v59i4.504

Prezoto, F.; Maciel, T.T.; Detoni, M.; Mayorquin, A. Z.; Barbosa, B.C. (2019) Pest Control Potential of Social Wasps in Small Farms and Urban Gardens. Insects, 10: 192-202. doi: 10.3390/insects10070192

Richards, O. W. (1978) Social wasps of the Americas, excluding the Vespinae. London, British Museum (Natural History).

Richter, M. R. (2000) Social wasp (Hymenoptera: Vespidae) foraging behavior. Annual Review of Entomology, 45: 121-150. doi: 10.1146/ annurev.ento.45.1.121

Santana, J. P.; Gonring, A. H. R.; Picanço, M. C.; Ramos, R. S.; Martins, J. C.; Ferreira, D. O. (2012) Natural biological control of Diaphania spp. (Lepidoptera: Crambidae) by Social Wasps. Sociobiology, 59: 561-571. doi: 10.13102/sociobiology.v59i2.618

Somavilla, A., Oliveira, M. L.; Silveira, O. T. (2014) Diversity and aspects of the ecology of social wasps (Vespidae, Polistinae) in Central Amazonian 'terra firme' forest. Revista Brasileira de Entomologia, 58: 349-355. doi: 10.1590/s0085-56262014005000007

Zucchi, R.; Sakagami, S. F.; Noll, F. B.; Mechi, M. R.; Mateus, S.; Baio, M. V.; Shima, S. N. (1995) Agelaia vicina, a swarm-founding polistine with the largest colony sizy among wasps and bees (Hymenoptera: Vespidae). Journal of the New York Entomological Society, 103: 129-137. 